NOTE

\title{
STATE ATTORNEY FEE SHIFTING STATUTES: ARE WE QUIETLY REPEALING THE AMERICAN RULE?
}

I

INTRODUCTION

The ordinary and historical rule in the United States has been that individual litigants are responsible for their own attorney fees.' Recently, however, this American rule has undergone extensive examination and has received a fair amount of criticism. ${ }^{2}$ Indeed, there seems to be some basis for this criticism of the American rule-often, it leads to socially undesirable results. For example, requiring individual litigants to pay their own attorney fees makes the pursuit of small meritorious claims cost-ineffective. ${ }^{3}$ Further, the poorer litigant may find himself in an unequal bargaining position with respect to his richer opponent whose enormous resources can finance prolonged litigation. ${ }^{4}$ Deviation from the American rule might ameliorate such problems and lead to other socially desirable results. For example, in many situations an award of attorney fees to successful litigants might promote certain public interests. ${ }^{5}$ Attorney fee shifting can also be used as an effective deterrent against frivolous suits and dilatory and bad faith tactics. ${ }^{6}$

In response to these concerns, both Congress and state legislatures have increasingly enacted statutes to relieve the hardships of the American rule for certain litigants. This note surveys and examines one of the states' responses to the American rule, that is, the enactment of attorney fee shifting statutes.

To analyze state statutory responses to the American rule, the authors conducted an historical and descriptive survey of those statutes of the fifty states and the District of Columbia which empower courts to require a litigant to pay his

1. See Alyeska Pipeline Serv. Co. v. Wilderness Soc'y, 421 U.S. 240, 247 (1975). See generally Leubsdorf, Toward a History of the American Rule on Attomey Fee Recovery, LAW \& ConTEMP. Probs., Winter 1984, at 9.

2. See, e.g., Ehrenzweig, Reimbursement of Counsel Fees and the Great Society, 54 CALIF. L. REV. 792 (1966); Kuenzel, The Attomey's Fee: Why Not a Cost of Litigation?' 49 IowA L. REV. 75 (1963); McLaughlin, The Recovery of Altomey's Fees: A New Method of Financing Legal Services, 40 FordhaM L. Rev. 761 (1972); Comment, Court Awarded Attomey's Fees and Equal Access to the Court, 122 U. PA. L. REv. 636, 648-55 (1974).

3. Mause, Winner Takes All: A Re-Examination of the Indernity System, 55 Iowa L. REV. 26, 33 (1969); Posner, An Economic Approach to Legal Procedure and Judicial Administration, 2 J. LEGAL STUD. 399, 437-38 (1973).

4. See Mause, supra note 3 , at 36.

5. See McLaughlin, supra note 2, at 767.

6. Rowe, Predicting the Effects of Altomey Fee Shifing, Law \& CONTEMP: Probs., Winter, 1984, at 139. 
opponent's attorney fees. In essence, this note provides a tabular and graphic display of the survey results, and an analysis of the most significant findings.

Section II provides an introductory explanation of the survey's initial goals and some of the survey's most significant findings. Section III details the methodology employed by the authors and discusses limitations on conclusions that can be drawn because of the methods used. Section IV provides a simple graphic and tabular display of the survey results and a brief quantitative analysis of the survey results. Finally, Section $V$ explores the actual impact, if any, which these statutes have had on the American rule.

\section{II \\ Survey Purposes}

Initially, the authors hoped that a survey of state attorney fee shifting would provide some answers concerning the existence, growth, and effect of these statutes. To answer these questions, the authors identified a number of purposes or goals to be accomplished by the survey, and then devised the survey to accomplish these purposes.

The most important goal of the survey was to provide an accurate, descriptive tabulation of existing state attorney fee shifting statutes. The authors feel fairly confident that the statutory survey accomplished this goal. In the 51 jurisdictions surveyed, the authors uncovered and evaluated approximately 2,000 attorney fee shifting statutes. ${ }^{7}$ Thus, this survey probably represents the most current comprehensive tabulation of state attorney fee shifting statutes.

Besides this obvious goal, however, the authors identified some additional objectives of the survey. First, the survey was designed to identify the predominant methods of effectuating a fee shift by statute. For example, the survey revealed that, unlike the English rule which grants attorney fees to the prevailing litigant, the vast majority of state attorney fee shifting statutes allow fee shifting only to prevailing plaintiffs. ${ }^{8}$ Second, the authors sought to identify those areas in which state legislatures are apt to provide for attorney fee shifting. The survey proved to be most helpful in answering this question. Although the survey results showed that states, on the whole, enact a large number of fee shifting statutes that deal with judicial procedure, it also demonstrated that legislatures have provided for fee shifting in a wide number of other areas. ${ }^{9}$ The authors also sought to determine whether a state's population size, population concentration, or geographic location within the Union had any effect on the propensity of its legislature to enact attorney fee shifting statutes. Although the survey provided no clear answer to this question, the results did show that Eastern states, on the average, have substantially fewer attorney fee shifting statutes per state than the rest of the nation. ${ }^{10}$

7. See infra p. 323 .

8. See infra p. 331

9. See infra p. 329.

10. See infra p. 339. 
The survey was also designed to provide an historical breakdown of attorney fee shifting statutes. Such a breakdown, it was hoped, could possibly provide insight into future trends. For example, the survey revealed the enactment of a large number of fee shifting statutes in the last two decades. ${ }^{11}$ Indeed, the continuation in recent years of high rates of enactment suggests no early slackening of this pace of legislative activity.

Finally, the most ambitious goal of the survey was to determine what extent, if any, the American rule - that each litigant pay his own attorney fee-had been affected by the enactment of these fee shifting statutes. Unfortunately, the survey results failed to provide a complete and satisfactory answer to this question since an in-depth examination of each statute's judicial application proved prohibitively time consuming. Nevertheless, a limited scan of reported cases that used these statutes did reveal that attorney fee shifting statutes were making some inroads into the American rule. ${ }^{12}$ Indeed, an examination of this question suggested that one factor impeding the impact of these statutes upon the American rule may be litigant and attorney ignorance of the existence of such statutes.

\section{III}

\section{METHODOLOGY}

The authors began the survey by searching the codes of the fifty states and the District of Columbia ${ }^{13}$ for those statutes ${ }^{14}$ which authorize attorney fee shifting. The comprehensiveness of the search, however, was constrained by three factors. First, the search was limited to those statutes which had been indexed under the "attorney" or "attorney fees" section of each state's code index. ${ }^{15}$ Second, the survey was limited to statutes currently in force. Indeed, statutes currently in force, as compared to repealed statutes, are most relevant to the purposes of this survey since the survey attempts to provide a descriptive tabulation of existing attorney fee shifting statutes. Finally, the survey concentrated solely on those statutes that empower courts to require one party to pay the other party's attorney fees. Thus, statutes that merely sanction or limit the right to provide contractually for the payment of attorney fees or that provide for reimbursement for courtappointed attorneys were not included.

Despite these limitations, however, the search of the codes still required the authors to examine approximately $4,000-5,000$ statutes. $^{16}$ Of these statutes, 1,974 of them were found to be "attorney fee shifting" statutes.

Upon discovery of a fee shifting statute, the authors tabulated it according to the following features: ${ }^{17}$

(1) State;

\footnotetext{
11. See infra pp. $340-41$.

12. See infra p. 345 .

13. For purposes of this note, the District of Columbia is included in the term "states."

14. The authors surveyed both state statutes and state rules of civil procedure.

15. This limitation was necessary because of time constraints.

16. This statutory survey was conducted by the authors over a one-year period and covered all current statutes enacted before 1983 .

17. These variables are discussed at length later in this article. See infra pp. 324-28.
} 
(2) Geographic region of the country;

(3) Statehood year;

(4) State population (large, medium, or small);

(5) State population concentration (urban or rural);

(6) Enactment year;

(7) Subject matter;

(8) Beneficiary of fee shift;

(9) Whether fee shifting is mandatory or discretionary; and

(10) The standard, if any, the court is to follow in awarding attorney fees;

(11) Calculation of the fee award; and

(12) Purpose(s) of the statute.

Subsequently, the authors devised a computer format to allow for a correlation of these variables among the 1,974 statutes and entered the information on each evaluated statute onto a single record in the computer file, resulting in $1,974 \mathrm{com}-$ puter records. Using this data base, the authors could search through all the statutes and identify those statutes with a common variable or combination of variables.

\section{A. State-Specific Variables}

Each statute record contains five state-specific variables: state, geographic region, statehood year, population, and population concentration. Inclusion of these variables on each file allowed the authors to test simple hypotheses such as the prevalence of fee shifting statutes in the Northeast versus the South, or in large states versus small states. The following provides a brief explanation of these variables.

Besides a state-by-state breakdown, the authors grouped the states into nine geographic regions: New England, ${ }^{18}$ Mid-Atlantic, ${ }^{19}$ Southeastern, ${ }^{20}$ Southern, ${ }^{21}$ South Central, ${ }^{22}$ North Central, ${ }^{23}$ Midwest, ${ }^{24}$ Mountain, ${ }^{25}$ and Pacific. ${ }^{26}$ The statehood variable marks the year that the state was admitted to the Union.

Each state was also placed in one of three categories based upon its population. Those states with populations greater than 7.5 million were considered large

18. Those states classified as New England states are: Connecticut, Maine, Massachusetts, New Hampshire, Rhode Island, Vermont.

19. Those states classified as Mid-Atlantic states are: Delaware, District of Columbia, Maryland, New Jersey, New York, Pennsylvania, West Virginia.

20. Those states classified as Southeastern states are: Kentucky, North Carolina, Tennessee, Virginia.

21. Those states classified as Southern states are: Alabama, Florida, Georgia, Mississippi, South Carolina.

22. Those states classified as South Central states are: Arkansas, Louisiana, Missouri, Oklahoma, Texas.

23. Those states classified as North Central states are: Illinois, Indiana, Michigan, Ohio, Wisconsin.

24. Those states classified as Midwest states are: Iowa, Kansas, Minnesota, Nebraska, North Dakota, South Dakota.

25. Those states classified as Mountain states are: Arizona, Colorado, Idaho, Montana, Nevada, New Mexico, Utah, Wyoming.

26. Those states classified as Pacific states are: Alaska, California, Hawaii, Oregon, Washington. 
states; ${ }^{27}$ those states with populations less than 7.5 million but greater than 2 million were classified as medium states; ${ }^{28}$ and those states with populations less than 2 million were considered small states. ${ }^{29}$ Naturally, this variable, considered alone, is a comparatively rough statistic since it fails to take into account the physical area encompassed by the state or the percentage of the population living in urban versus rural areas. Therefore, an additional variable-population concentrationwas included in the survey. Thus, those states with over $50 \%$ of their population living in metropolitan areas were classified as urban, ${ }^{30}$ while those with less than $50 \%$ of their population living in metropolitan areas were classified as rural. ${ }^{31}$

\section{B. Statute-Specific Variables}

Each statute record also contains seven statute-specific variables: year of enactment, subject matter, beneficiary, discretionary/mandatory, standard, calculation, and purpose(s).

Year of enactment is the year in which the attorney fee shifting portion of the statute was adopted, either as a tack-on amendment to an existing statute or as part of the original statute. The authors experienced some difficulty in pinpointing enactment years for some statutes because the state codes, at times, failed to provide sufficient detail concerning the historical evolution of the statute. Fortunately, the vast majority of the codes were sufficiently detailed so as to permit this variable to be reasonably accurate. ${ }^{32}$

The authors then determined the subject matter of each statute, classifying each statute according to one of twenty-six categories. A detailed list of these categories is provided below. ${ }^{33}$ It is important to note that the vast majority of the

27. The nine states designated as large states are: California, Florida, Illinois, Michigan, New Jersey, New York, Ohio, Pennsylvania, and Texas.

28. The 24 states designated as medium states are: Alabama, Arizona, Arkansas, Colorado, Connecticut, Georgia, Indiana, Iowa, Kansas, Kentucky, Louisiana, Maryland, Massachusetts, Minneosta, Mississippi, Missouri, North Carolina, Oklahoma, Oregon, South Carolina, Tennessee, Virginia, Washington, and Wisconsin.

29. The 18 states designated as small states are: Alaska, Delaware, District of Columbia, Hawaii, Idaho, Maine, Montana, Nebraska, Nevada, New Hampshire, New Mexico, North Dakota, Rhode Island, South Dakota, Utah, Vermont, West Virginia, and Wyoming.

30. The 32 states designated as urban are: Alabama, Arizona, California, Colorado, Connecticut, Delaware, District of Columbia, Florida, Georgia, Hawaii, Illinois, Indiana, Louisiana, Maryland, Massachusetts, Michigan, Minnesota, Missouri, Nevada, New Jersey, New York, Ohio, Oklahoma, Oregon, Pennsylvania, Rhode Island, Tennessee, Texas, Utah, Virginia, Washington, and Wisconsin.

31. The 19 states designated as rural states are: Alaska, Arkansas, Idaho, Iowa, Kansas, Kentucky, Maine, Mississippi, Montana, Nebraska, New Hampshire, New Mexico, North Carolina, North Dakota, South Carolina, South Dakota, Vermont, West Virginia, and Wyoming.

32. To insure the accuracy of this variable, the authors occasionally checked older state code editions to see if the present code editors were providing an accurate history of the statute.

33. The following subject matter categories were used:

(1) Agriculture;

(2) Antitrust: monopoly, price discrimination, restraints of trade, unfair trade practices;

(3) Assessments: city liens, city services, lien enforcement;

(4) Banking and commercial law: dishonored checks, general banking laws;

(5) Civil rights;

(6) Consumer transactions: consumer contract claims, consumer financing transactions, warranty violations;

(7) Corporate law: accounting actions, derivative actions, dissenting shareholder rights; 
statutes easily fit into the specified categories. Occasionally, however, a statute appeared to fit within more than one of the enumerated categories. In those instances, the authors chose the subject matter category which most appropriately represented the statute's major theme.

The beneficiary variable identifies the litigant whom the statute designates as the recipient of the attorney fee award. The authors classified the beneficiaries according to the following categories: prevailing party, prevailing plaintiff, prevailing defendant, either party, ${ }^{34}$ plaintiff, defendant, aggrieved party, ${ }^{35}$ prevailing moving party, specific prevailing party (for example, prevailing farmer or prevailing creditor), prevailing appellee, and prevailing appellant.

The mandatory/discretionary variable indicates whether the statute on its face requires the court to award attorney fees (mandatory) to the designated beneficiary or whether the award is left to court discretion (discretionary). In making this determination, the authors relied upon the statutory language; the use of the word "may" indicated discretion, while the use of the word "shall" or "must" indicated the award was mandatory. ${ }^{36}$

The next variable considered was the standard, if any, which the court is to apply to determine whether a potential beneficiary's situation merits an award of attorney fees. ${ }^{37}$ Thus, this variable requires a court to find either that the paying

(8) Crime: pawnbroker violations, stolen goods, victim reparations;

(9) Debtor/Creditor relations: bankruptcy, garnishment;

(10) Education;

(11) Environmental Protection: land and water preservation; natural resource protection, nuisance claims;

(12) Family law: child custody, divorce, domestic relations;

(13) General Business Transactions: business regulation, construction law, controversies between businesses, franchise regulation;

(14) General litigation: appeals, discovery, frivolous and bad faith claims or defenses, small claims;

(15) Insurance;

(16) Labor relations: unfair labor practices, wage disputes;

(17) Property: eminent domain actions, personal and real property actions;

(18) Public agency or official violations: elections, public meeting laws;

(19) Public health and social welfare: licensing laws:

(20) Public utilties: common carriers, railroads, telephones;

(21) Rental housing: innkeeper relations, landlord/tenant actions;

(22) Securities laws;

(23) Tax laws;

(24) Torts: confidentiality breaches, invasion of privacy, libel and slander, property destruction;

(25) Worker's compensation; and

(26) Water laws.

34. "Either party" statutes vest the court with complete discretion in choosing the beneficiary of a fee shift. Thus, a losing party, if the court so decides,, may have his attorney fees paid.

35. "Aggrieved party" attorney fee shifting statutes are found in the state civil procedure rules. In these statutes, one party has acted in less than good faith in observing some of the state rules of civil procedure. Accordingly, the beneficiary is the party that has been "aggrieved" by such conduct.

36. Although court interpretation of the statutory language might deviate somewhat from the literal meaning in some instances, time constraints did not permit the authors to research judicial interpretation of the statutes.

37. The following standards are found in the statutes:

(1) Ability to pay;

(2) Bad faith conduct;

(3) Vexatious litigation without cause;

(4) Condition precedent exists;

(5) Dilatory tactics; 
litigant took a specified action or that a certain condition exists before awarding the attorney fee. For example, some statutes require, before a fee shift may occur, a finding that the losing litigant engaged in bad faith or willful conduct.

The next variable against which each statute was evaluated was the method of fee calculation. This variable looks at the statutory guidance, if any, given to the courts in determining the amount to be awarded. ${ }^{38}$

The final variable considered was purpose. The authors started with the assumption that there was a motivating force behind the legislatures' enactments of the attorney fee shifting statutes. It was often difficult, however, to identify the exact legislative purpose behind a fee shifting statute because it often appeared that there was more than one purpose motivating the legislature. Therefore, each computer record was designed to accommodate up to three identifiable purposes. Again, the accuracy and efficiency of the "purpose variable" are limited by the inability of the authors to delve into each statute's legislative history. Nevertheless, the authors believe that the results are sufficiently accurate to allow for some significant general conclusions.

Relying heavily upon a classification system developed by Professor Thomas Rowe of Duke University School of Law, ${ }^{39}$ the authors used six broad categories in evaluating each attorney fee shifting statute. These six purposes are as follows:

(1) Full Compensation:40 Under the American rule, a prevailing plaintiff's effective recovery will usually be the awarded damages minus the costs of the suit. Full compensation statutes seek to make the designated beneficiary whole; that is, the award of attorney fees allows the winning party to be fully compensated for his legal injuries. This type of statute also generally assumes that there was some degree of fault on the part of the losing party.

(2) Litigation Control: ${ }^{41}$ These statutes are designed to prevent abuse of the judicial system. For example, litigation control statutes would provide for an award of attorney fees when an opposing party brings a frivolous claim or uses a defense in bad faith.

(6) Frivolous claims;

(7) If plaintiff prevails, defendant must have acted willfully or knowingly, if defendant prevails, plaintiff must have acted in bad faith;

(8) If plaintiff prevails, no standard, if defendant prevails, plaintiff must have acted in bad faith;

(9) Knowing or willful actions;

(10) Negligent actions; and

(11) To prevent fee shifting, substantial justification or good faith must be shown.

38. The following methods of calculating the fee award are found in the statutes:

(1) An "appropriate and moderate" fee;

(2) A fixed dollar amount;

(3) A fixed upper dollar ceiling;

(4) A maximum percentage of recovery;

(5) Out of pocket costs;

(6) A "reasonable" fee;

(7) No calculation method; and

(8) Percentage of the amount awarded

39. Rowe, The Legal Theory of Altorney Fee Shifing: A Critical Overview, 1982 DukE L.J. 651.

40. Id. at 657-59.

41. Id. at 665-66. 
(3) Public Interest/Private Attorney General:42 These statutes encourage specific suits because the litigation or litigation result confers benefits on the general public. These statutes also provide encouragement to those litigants who could not ordinarily bear the cost of such public interest suits.

(4) Punitive/Deterrent: ${ }^{43}$ These statutes use the award of attorney fees to punish the losing party for misconduct and to deter such misconduct in the first instance. These statutes typically deal with areas where the defendant's level of fault is higher than mere negligence.

(5) Equalization: ${ }^{44}$ These statutes reflect an attitude that in certain areas there is a need to equalize the litigation strengths of the parties. Thus, the legislature may provide for an award of attorney fees to one party in order to correct a financial imbalance between the parties.

(6) Indemnity:45 These statutes reflect the legislature's belief that a losing party should pay the winning party's attorney fees. Thus, a party is not required to bear the financial burden of proving a justifiable claim. This type of fee shift most closely resembles the English rule.

Finally, each computer record contains an abbreviated description of each encoded statute. ${ }^{46}$ Through careful use of this brief description, the authors found that more in-depth and particularized searches, especially with respect to subject matter, could be undertaken.

\section{IV}

\section{ANALYSIS}

This section presents in tabular and graphic form the results of the survey along with a brief analysis of the most significant results. Specifically, part A identifies those areas in which state legislatures are enacting fee shifting laws and examines the most common methods of effecting fee shifting by statute. Part B examines the correlation between fee shifting statutes and the state-specific variables. Finally, part $\mathrm{C}$ focuses on the historical trends in enactment of fee shifting statutes.

\section{A. Predominant Methods of Attorney Fee Shifting by Statute}

1. Subject Matter. By providing a numerical and percentage breakdown of the 1,974 attorney fee shifting statutes by the twenty-six designated categories, ${ }^{47}$ table 1 identifies those areas in which state legislatures are enacting fee shifting laws. Table 1 also reports in the far right hand column the number of states with at least one statute dealing with that subject matter.

The data in table 1, however, not only identify the major areas in which fee

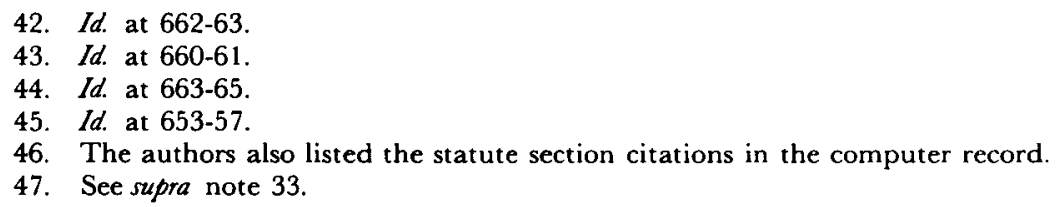




\section{TABLE 1}

SUBJECT MATTER

\begin{tabular}{|c|c|c|c|}
\hline SUBJECT MATTER & TOTAL & PERCENTAGE & STATE COVERAGE \\
\hline General Litigation & 355 & 18.0 & 50 \\
\hline Property & 195 & 9.9 & 37 \\
\hline Consumer & 132 & 6.7 & 34 \\
\hline Family & 121 & 6.1 & 33 \\
\hline Labor & 110 & 5.6 & 34 \\
\hline General Trade Regulation & 107 & 5.4 & 33 \\
\hline State Violations & 90 & 4.6 & 29 \\
\hline Rental Housing & 71 & 3.6 & 26 \\
\hline Insurance & 71 & 3.6 & 36 \\
\hline Assessments & 70 & 3.6 & 23 \\
\hline Utilities & 64 & 3.2 & 21 \\
\hline Antitrust & 58 & 2.9 & 27 \\
\hline Corporations & 56 & 2.8 & 25 \\
\hline Torts & 56 & 2.8 & 25 \\
\hline Civil Rights & 54 & 2.7 & 28 \\
\hline Environment & 49 & 2.5 & 21 \\
\hline Debtor/Creditor & 44 & 2.2 & 21 \\
\hline Agriculture & 42 & 2.1 & 13 \\
\hline Worker's Compensation & 37 & 1.9 & 22 \\
\hline Public Health & 35 & 1.8 & 18 \\
\hline Crime & 31 & 1.6 & 22 \\
\hline Banking & 30 & 1.5 & 20 \\
\hline Water & 30 & 1.5 & 13 \\
\hline Taxation & 28 & 1.4 & 16 \\
\hline Securities & 23 & 1.2 & 18 \\
\hline Education & 15 & .8 & 11 \\
\hline TOTAL & 1974 & 100.0 & 51 \\
\hline
\end{tabular}

shifting is occurring; they also yield two interesting findings. First, as noted above, general litigation or procedural statutes are the single most prevalent type of attorney fee shifting statutes; indeed, procedural attorney fee shifting statutes are found in 50 of the 51 surveyed jurisdictions. ${ }^{48}$ Nevertheless, nonprocedural statutes account for over $80 \%$ of all state attorney fee shifting statutes. The presence of this many nonprocedural attorney fee shifting statutes in so many diverse areas reflects a fairly strong legislative effort, on the whole, to deviate from the American rule in substantive areas. Second, although-as noted by table 1-attorney fee shifting statutes have been enacted in a number of diverse areas, the authors often

48. A partial explanation for the high number of general litigation statutes and rules awarding at torney fees is that about three-quarters of the states have adopted rules modeled on the Federal Rules of Civil Procedure, which provide for attorney fee awards when an opposing party is at fault. See Fed. R. Civ. P. $30(\mathrm{~g}), 37(\mathrm{a})-(\mathrm{d}), 56(\mathrm{~g})$. 
found that a large number of states had enacted similar fee shifting statutes. For example, 23 states have enacted similar eminent domain statutes which award prevailing defendant landowners attorney fees in eminent domain actions brought by the state or other condemning parties. In addition, a number of states have similar statutes providing for attorney fee shifting in "dishonored check" cases.

The authors found two possible explanations for the presence of similar statutes in a wide number of states. First, a number of state legislatures often enact statutes as part of national movements that encourage the enactment of "uniform statutes," and these model statutes often contain subsidiary sections providing for fee shifting. For example, that general litigation statutes exist in almost every state is mostly explained by the fact that many states have merely incorporated the Federal Rules of Civil Procedure and its fee shifting provisions into their own rules. Indeed, a number of states have enacted uniform statutes with affixed fee shifting provisions in such areas as child custody laws, consumer credit, franchiseefranchisor relations, and insurance.

The second possible explanation for the prevalence of similar state attorney fee shifting statutes is that states have recognized that in certain areas a strict application of the American rule would work an injustice on one of the litigants. For example, recognizing that a strict application of the American rule in divorce cases would severely handicap the poorer-possibly, nonworking-spouse, a number of states have enacted similar fee shifting statutes that grant the court total discretion in divorce proceedings to decide which party, win or lose, is entitled to attorney fees. This type of reasoning can also help explain the enactment of similar state statutes dealing with mechanics liens, child support payments, and unpaid wages.

2. Beneficiary. Table 2 provides a tabular breakdown of the beneficiaries of state attorney fee shifting statutes. Surprisingly, over $54 \%$ of fee shifting statutes desig-

TABLE 2

\section{BENEFICIARY}

BENEFICIARY
Prevailing plaintiff
Prevailing party
Prevailing defendant
Aggrieved party
Either party
Moving party
Specific prevailing party
Defendant
Plaintiff
Prevailing appellee
Prevailing appellant
Other

TOTAL
TOTAL

1,073

383

165

152

70

41

30

21

15

10

6

8

1974
PERCENTAGE

54.4

19.4

8.4

7.7

3.6

2.1

1.5

1.1

.8

.5

.3

.4

100.0 
nate the prevailing plaintiff as the beneficiary of the fee shift while only $19 \%$ of such states designate the prevailing party as beneficiary. ${ }^{49}$ This statistic is significant in itself in that it indicates that states, in response to the American rule, have not sought to embrace the English rule which designates the victorious litigant or prevailing party as the beneficiary of the fee award. Indeed, the large number (1591) of nonprevailing party attorney fee shifting statutes seems to reflect a new type of fee shifting. That is, rather than allowing the litigation's outcome to be the sole determinant of the beneficiary, the state legislatures have made prelitigation decisions favoring one party over another. And, as noted by table 2 , legislatures have tended to favor making judicial action more attractive for plaintiffs.

At this point, it is also appropriate to inquire whether a fee shifting statute's subject matter influences the designation of the beneficiary and whether this influence can be explained. A simple correlation of subject matter with beneficiary demonstrated that the beneficiary variable did indeed vary according to subject matter category. For example, consumer fee shifting statutes are $74 \%$ prevailing plaintiff statutes. Since most plaintiffs in these cases will be consumers, this favoritism for plaintiffs reflects a favoritism for consumers. Similarly, prevailing plaintiff statutes account for $79 \%$ of antitrust fee shifting statutes, possibly reflecting a legislative belief that meritorious antitrust suits by poorer litigants should not be discouraged because of the length and cost of such litigation.

In contrast, the family law and general litigation categories have a relatively low number of prevailing plaintiff fee shifting statutes. Of the 121 family law statutes, only 34 are prevailing plaintiff statutes, while 46 of these statutes are either party statutes. ${ }^{50}$ Since either party statutes vest the court with total discretion in selecting the fee shift beneficiary, the prevalence of either party statutes is explained by the legislatures' desire to allow the court total discretion in order to equalize the litigating strengths of the parties in divorce and child custody proceedings. Of the 355 general litigation fee shifting statutes, only 27 are prevailing plaintiff statutes. Indeed, most of the general litigation fee shifting statutes are aggrieved party statutes. This low number of prevailing plaintiff statutes, however, is explained when one considers the purpose behind general litigation statutes. The high prevalence of prevailing plaintiff and prevailing defendant fee shifting statutes in nonprocedural areas suggests that the legislatures are very much concerned with helping or protecting certain litigants. In contrast, however, most procedural fee shifting statutes are less concerned with protecting a certain party and more concerned with preventing abuse of the judicial process. Thus, general litigation statutes will tend to identify the beneficiary in terms of preventing abuses of the judicial system-aggrieved party, prevailing moving

49. Of particular interest are those 36 statutes which award attorney fees to the plaintiff or to the defendant even though that party may lose. This absolute right to attorney fees is somewhat tempered in that virtually all of these statutes require the judge either to exercise discretion in making an award or to find a condition exists before the award can be made. See, e.g., Cal. LaB. CoDk $\$ 5710$ (West Supp. 1984) (employer who requests deposition from employee during workman's compensation hearing may be required to pay employee's attorney fee).

50. Family law statutes account for 46 of the 70 either party statutes. 
party, or prevailing party-rather than seeking to protect specific parties-prevailing plaintiff, prevailing defendant, or prevailing specific party. That the beneficiary variable does fluctuate acording to subject matter and that this variance can be rationally explained suggests that the legislatures have for the most part engaged in rational decisionmaking when choosing the beneficiary.

3. Mandatory/Discretionary. Table 3 indicates that over $64 \%$ of attorney fee shifting statutes mandate a court award of attorney fees, while $34 \%$ grant the court discretion whether to make the fee award to the designated beneficiary. These statistics, however, must not be read to indicate that in $64 \%$ of fee shifting statutes, the court may not exercise any discretion over the fee award. Many of the mandatory statutes also have a standard that the court must apply in order for the beneficiary to be awarded his attorney fee. Accordingly, the courts will retain some discretion when deciding whether the standard has been met. For example, many general litigation statutes mandate an attorney fee award unless the paying party can prove his actions were substantially justified. Thus, the court must exercise its discretion in determining whether "substantial justification" existed. In fact, 342 mandatory statutes have accompanying standards. Thus, in the majority of attorney fee shifting statutes, the court will be exercising a certain amount of discretion. Nevertheless, that such a large number of statutes vest the court with virtually total discretion in whether or not to award attorney fees is in itself significant. Such a practice represents a significant departure from the English rule which mandates an award to the prevailing party; moreover, the presence of a discretionary statute represents the legislature's belief that the awarding of attorney fees in certain areas requires a case-by-case balancing of the equities.

TABLE 3

\section{MANDATORY/DISCRETIONARY}

Mandatory/Discretionary
Mandatory
Discretionary
Mandatory for plaintiff or
discretionary for defendant
Combination
Unclear

TOTAL

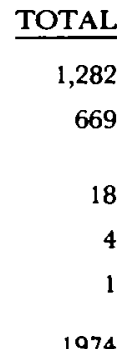

1974
PERCENTAGE

65.0

33.9

9

.2

1

100.0

It also is appropriate to inquire whether this variable seems to be influenced by the statute's subject matter or beneficiary. These correlations produced few significant results, however. A correlation between subject matter and the mandatory/discretionary variable reveals only one subject matter which has predominantly discretionary statutes. Of the 121 family law statutes, 106 are discretionary statutes. Such a result, however, seems logical in the family law statutes, since these statutes mostly deal with controversies - child custody and divorce 
proceedings - that require the courts to balance the equities. ${ }^{51}$ Finally, a correlation between beneficiary and the mandatory/discretionary variable produced two interesting results: (1) prevailing party attorney fee shifting statutes are $37 \%$ discretionary while (2) prevailing plaintiff statutes are only $27 \%$ discretionary.

4. Standard. Our survey of the standards that govern courts when awarding attorney fees revealed that the most popular means of drafting a statute is without a standard; indeed, only $29 \%$ of state attorney fee have any standard to follow. Nevertheless, with respect to those statutes with standards, two items merit note. First, bad faith and substantial justification standards are confined mostly to general litigation statutes. In contrast, condition precedent and knowing or willful standards are the most common standards for nonprocedural attorney fee shifting statutes.

\section{TABLE 4}

\section{STANDARD}

\section{STANDARD}

No standard in statute

Unless there was substantial justification or good faith

Condition precedent

Bad faith

Knowing or willful

Frivolous claim

Prevailing plaintiff no standard/Prevailing defendant, plaintiff acts in bad faith

Vexatious and without cause

Prevailing plaintiff, defendant acts knowingly; prevailing defendant, plaintiff acts in bad faith

Unless plaintiff's claim is frivolous

Ability to pay

Negligent

Combination standard

Dilatory tactics

State may not recover

TOTAL
TOTAL

1423

157

103

97

68

56

22

15

8
7
5
5
4
3
1

1,974

\section{PERCENTAGE}

72.1

8.0

5.2

4.9

3.4

2.8

1.1

.8

.4

.35

.3

.3

.2

.2

.1

100.0

5. Calculation. Few statutes provide an exact formulation for calculating the attorney fee award. Rather, as noted by table 5, the vast majority of attorney fee statutes merely require the court to award "reasonable fees" to the beneficiary. In

51. See also supra note 34 . 
TABLE 5

Calculation

CALCULATION
Reasonable
No calculation standard
Percentage of the amount awarded
Fixed upper dollar ceiling
Out of pocket
Fixed maximum percentage
Fixed dollar amount
Appropriate \& moderate
Other

\begin{tabular}{r} 
TOTAL \\
\hline 1,602 \\
205 \\
41 \\
36 \\
32 \\
24 \\
18 \\
2 \\
14
\end{tabular}

PERCENTAGE

81.2

10.4

$41 \quad 2.1$

$36 \quad 1.8$

$32 \quad 1.6$

$24 \quad 1.2$

$18 \quad .9$

2 .1

$14-7$

addition, over $10 \%$ of the attorney fee shifting statutes provide no guidance to the court on the amount to be awarded. That over $90 \%$ of state attorney fee shifting statutes provide such little guidance on the method of calculating the fee shift might initially be surprising when one considers the high cost of litigation. This lack of guidance on calculation, however, may merely be due to the legislatures' belief that a fee award can best be determined on a case-by-case basis. Nevertheless, there are a number of statutes which specifically limit the amount to be awarded, through using either a fixed dollar amount or a fixed percentage of the award..$^{2}$

6. Purpose. Finally, it is appropriate to examine briefly the seemingly major purposes behind attorney fee shifting statutes. As noted in table 6 , full compensation

TABLE 6

PURPOSE

\begin{tabular}{lcc} 
PURPOSE & \multicolumn{1}{c}{ TOTAL } & PERCENTAGE \\
\cline { 2 - 3 } Full compensation & 742 & $37.6 \%$ \\
Punitive & 647 & $32.8 \%$ \\
Litigation control & 570 & $28.9 \%$ \\
Public interest & 324 & $16.4 \%$ \\
Indemnity & 207 & $10.5 \%$ \\
Equalization & 202 & $10.2 \%$ \\
TOTAL & 2692 & $136.4 \%$ \\
a These percentages reflect the percent of attorney fee shifting statutes that have the following purposes. &
\end{tabular}

52. As noted by table 5, a number of statutes fix the amount which can be awarded as attorney fees. Many of the fixed dollar amounts, however, are out of date with present day attorney prices. Thus, a fixed dollar fee shifting statute should be continually revised in order to accommodate changing economic conditions such as inflation. 
is the most prevalent legislative purpose behind attorney fee shifting statutes; over $37 \%$ of all such statutes have full compensation as a purpose. ${ }^{53}$ Of interest, however, is the low percentage of statutes with indemnity as a purpose. As noted previously, indemnity purpose statutes most likely resemble the English rule. ${ }^{54}$ Thus, the low percentage of these statutes again reinforces our previous conclusion that states have not adopted the English rule. Finally, the low number of public interest fee shifting statutes, on the whole, demonstrates that states have not actively sought as extensively as might have been expected to use attorney fee shifting statutes as a means of promoting public welfare or public rights.

\section{B. State-Specific Variables}

This section focuses on two areas. First, it examines the apparent comprehensiveness of state fee shifting statute schemes and whether fee shifting laws are being enacted with equal vigor in all states. Second, this section explores the relationship between fee shifting statutes and three state-specific variables: state population, population concentration, and geographic region.

1. State Breakdown. As noted by table 7, the number of fee shifting statutes per state ranges from a high of 146 statutes in California to a low of 2 in North Carolina. Indeed, table 7 conclusively demonstrates that enactment of attorney fee shifting statutes has not been uniform across the states. To reach some general conclusions about the comprehensiveness of each state's scheme, however, it proves helpful to divide the 51 "states" into four groups: states with 0 to 20 fee shifting statutes; states with 21 to 50 fee shifting statutes; states with 51 to 75 fee shifting statutes; and states with more than 75 fee shifting statutes.

Twenty states have twenty or fewer fee shifting statutes. An analysis of these states using three guides suggests that, on the whole, these states have not made much of a legislative effort to deviate from the American rule.

First, although comprising slightly less than $40 \%$ of the surveyed jurisdictions, these states acount for only $9 \%$ of the states' attorney fee shifting laws. Second, general litigation statutes represent almost half of the statutes in these states, whereas such statutes only represent one-sixth of the statutes nationwide. The prevalence of these general litigation statutes demonstrates a lack of legislative concern with substantive attorney fee shifting laws. Finally, an analysis of the types of subject matters that are covered by these 20 states' attorney fee shifting laws reveals that the mean number of subject matters covered per state is roughly 5; for states with fewer than 10 statutes this number falls to 2 . Thus, the low number of attorney fee shifting statutes per state, the low number of subject

53. As noted by Dr. Pfennigstorf in this symposium, full compensation is the major purpose behind European fee shifting statutes. Pfennigstorf, The European Experience with Attomey Fee Shifting, Law \& CONTEMP. PROBS., Winter 1984 at 37.

54. See supra p. 328. 
TABLE 7

State BREakdown

\begin{tabular}{l} 
STATE \\
\hline California \\
Oregon \\
Florida \\
Minnesota \\
Montana \\
Texas \\
Louisiana \\
Nebraska \\
Oklahoma \\
Illinois \\
North Dakota \\
Pennsylvania \\
Arizona \\
Washington \\
Michigan \\
Iowa \\
Hawaii \\
Kansas \\
Connecticut \\
New Jersey \\
Mississippi \\
Wisconsin \\
Maine \\
South Carolina \\
Nevada \\
Ohio \\
Massachusetts \\
Vermont \\
Missouri \\
New York \\
Idaho \\
South Dakota \\
Utah \\
Alaska \\
Arkansas \\
Virginia \\
District of Columbia \\
Indiana \\
Delaware \\
Maryland \\
Georgia \\
New Mexico Island \\
Tennessee \\
Colorado \\
Kentucky \\
Alabama \\
West Virginia \\
\\
North Hampshire \\
Wina \\
Moming
\end{tabular}

TOTAL

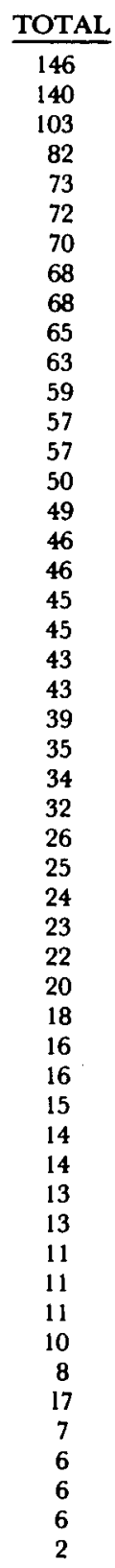

1974

\section{PERCENTAGE}

7.4

7.1

5.2

4.2

3.7

3.7

3.6

3.4

3.4

3.3

3.2

3.0

2.9

2.9

2.5

2.5

2.3

2.3

2.3

2.3

2.2

2.2

2.0

1.8

1.8
1.7
1.6

1.6

1.3

1.3

1.2

1.2

1.1

1.0

.9

8

.8

.8

.7
.7

.7
.7

.7
.7

.6

.6

.6

.5

.4

.4
.3

.3
.3

.3

.1

100.0
SUBJECT MATTER ${ }^{a}$ CONCENTRATION

26
25

24

21

18

22

21

18

24

22

22

17

18

16

19

19

14

19

20

19

16

16

16

14

11

13

11

13

13

13

12

9

11

4

9

8

7

6

5

8

5

6

3

2

2

2

4

2

1

26

Median

32

a Subject matter concentration refers to the number of subject matter categories in which at least one attorney fee shifting statute has been enacted in that state. 
matters covered per state, and the very high percentage of general litigation fee shifting statutes suggest that these 20 states have not taken any real comprehensive legislative action to deviate from the American rule.

Caution is required at this point, however. The small number of attorney fee shifting statutes alone, without any indication of the breadth of their applicability, is of less significance. For example Alaska, while having fewer than 20 attorney fee shifting statutes, has effectively legislated away the American rule. ${ }^{55}$

An analysis of the 17 states with 21 to 50 fee shifting statutes reveals that each state's fee shifting scheme is becoming more comprehensive. General litigation statutes account for only $19 \%$ of all fee shifting statutes in these states, reflecting a more vigorous move into substantive areas. Similarly, the mean number of subject matters covered per state has risen to 15 , also reflecting a broader fee shifting scheme.

The fee shifting scheme is even broader for those 10 states with 51 to 75 statutes. Among these states, the mean number of subject matters covered is 20 , and general litigation statutes account for only $14 \%$ of all fee shifting statutes. The remaining states-California (146), Florida (103), Minnesota (82), and Oregon (140) - account for $24 \%$ of the nation's fee shifting statutes. ${ }^{56}$ Unsurprisingly, general litigation statutes account for only $8 \%$ of all these statutes and the states have enacted attorney fee shifting statutes in virtually all of the subject matter categories-California (26), Oregon (25), Minnesota (25), and Florida (24).

The above analysis provides two important observations. First, the enactment of state attorney fee shifting statutes as a means to deviate from the American rule has not been a national phenomenon. Indeed, our analysis suggests that a large number of states have not mounted any real legislative effort to deviate from the American rule. Second, the fact that as fee shifting statutes per state increase the range of subject matters covered also increases suggests that states are not focusing fee shifting statutes in specific judicial areas. In fact, no state showed a tendency to focus predominantly on one substantive area while ignoring others when enacting attorney fee shifting statutes. Indeed, this apparent lack of legislative focus in enacting fee shifting laws may reflect that attorney fee shifting statutes are the result of pressure from various interest groups rather than the result of a coordinated legislative effort to systematically remove the American rule from certain areas.

\section{Other State-Specific Variables.}

a. Population. Table 8 shows that, on the whole, attorney fee shifting statutes are less prevalent in less populated states. Indeed, one might believe that a correlation exists between population and the number of attorney fee shifting statutes. Caution again is required, however, since the results may simply reflect a

55. See Alaska R. Civ. P. 82 (court has discretion to award attorney fees to prevailing party); see also ALASKa STAT. $\$ 9.06 .010$ (1983).

56. The high number of attorney fee shifting statutes in these four states accounts for much of the difference between the mean (32) and the median (38). 
TABLE 8

State Population

$\begin{array}{lccc}\text { Category } & \text { Total } & \text { Percentage } & \text { Per State } \\ \text { Large } & 595 & 30.1 & 66.1 \\ \text { Medium } & 892 & 45.2 & 37.2 \\ \text { Small } & 487 & 24.7 & 27.1\end{array}$

TABLE 9

State Population Concentration

$\begin{array}{lccc}\text { Category } & \text { Total } & \text { Percentage } & \text { Per State } \\ \text { Urban } & 1,419 & 71.9 & 44.3 \\ \text { Rural } & 555 & 28.1 & 29.2\end{array}$

lower level of legislative activity within less populated states rather than any particular treatment of attorney fees.

b. Population concentration. An initial analysis of table 9 suggests that rural areas are not as apt to enact as many fee shifting statutes as urban areas. By correlating large, medium, and small states with urban and rural states, however, one can see that such an initial assumption is misguided. When urban and rural states with similar populations are compared, as in table 10, the problems with such an assumption become apparent; the opposing mean and median numbers for urban and rural states with similar populations suggest that the urban/rural distinction has no real effect on the enactment of fee shifting statutes. In fact the high average for urban states shown in table 9 is mostly attributable to the large/urban states-an area in which no comparison can be made with rural states.

TABLE 10

Correlation of Population with Population Concentration

\begin{tabular}{|c|c|c|c|c|}
\hline \multirow[b]{3}{*}{ Large } & \multicolumn{2}{|l|}{ Urban } & \multicolumn{2}{|l|}{ Rural } \\
\hline & No. of States & $=9$ & & \\
\hline & $\begin{array}{l}\text { Mean } \\
\text { Median }\end{array}$ & $\begin{array}{l}=66.1 \\
=59\end{array}$ & No. of States & $=0$ \\
\hline & No. of States & $=17$ & No. of States & $=7$ \\
\hline Medium & $\begin{array}{l}\text { Mean } \\
\text { Median }\end{array}$ & $\begin{array}{l}=40.6 \\
=26\end{array}$ & $\begin{array}{l}\text { Mean } \\
\text { Median }\end{array}$ & $\begin{array}{l}=28.3 \\
=35\end{array}$ \\
\hline & No. of States & $=6$ & No. of States & $=12$ \\
\hline Small & $\begin{array}{l}\text { Mean } \\
\text { Median }\end{array}$ & $\begin{array}{l}=21.83 \\
=16\end{array}$ & $\begin{array}{l}\text { Mean } \\
\text { Median }\end{array}$ & $\begin{array}{l}=29.67 \\
=21\end{array}$ \\
\hline
\end{tabular}


c. Geographical region. As demonstrated by table 11, the number of attorney fee shifting statutes enacted by region varies significantly from a high of 81 fee shifting statutes per state in the Pacific region to a low of 9 fee shifting statutes per state in the Southeastern region. This statistic alone suggests that a state's geographical region may have an impact on the state's enactment of fee shifting statutes and, indeed, a closer examination of the regions reveals that a state's propensity to enact fee shifting statutes seems to be influenced by neighboring states' activity in enacting fee shifting statues.

TABLE 11

\section{Regional Distribution}

\begin{tabular}{|c|c|c|c|c|}
\hline Region & $\begin{array}{l}\text { Number } \\
\text { of States }\end{array}$ & $\begin{array}{c}\begin{array}{c}\text { Total } \\
\text { Statutes }\end{array} \\
\end{array}$ & $\begin{array}{c}\text { Percentage of } \\
\text { National Total } \\
\end{array}$ & $\begin{array}{c}\text { Mean Statutes } \\
\text { Per State } \\
\end{array}$ \\
\hline Pacific & 5 & 405 & 20.5 & 81.0 \\
\hline Midwest & 6 & 328 & 16.6 & 54.7 \\
\hline South Central & 5 & 250 & 12.7 & 50.0 \\
\hline Mountain & 8 & 231 & 11.7 & 28.9 \\
\hline North Central & 5 & 204 & 10.3 & 40.8 \\
\hline Southern & 5 & 199 & 10.1 & 39.8 \\
\hline Mid-Atlantic & 7 & 174 & 8.8 & 24.9 \\
\hline New England & 6 & 147 & 7.5 & 24.5 \\
\hline Southeastern & 4 & 36 & 1.8 & 9.0 \\
\hline
\end{tabular}

First, table 11 reveals that the four easternmost regions ${ }^{57}$ have the fewest attorney fee shifting statutes. In fact, 20 out of the 22 states in these four eastern regions have fewer than 50 statutes per state; while 12 of the remaining 29 states have more than 50 statutes per state. Second, an analysis of those states with fewer than 20 statutes reveals that these states are basically clumped together in two geographical groups: four states in the Mountain region ${ }^{58}$ and eleven states in the South and Southeastern regions of the country. ${ }^{59}$ An analysis of the other states also reveals that many neighboring states are enacting similar numbers of attorney fee shifting laws. Thus, although the data are far from conclusive, the above analysis does suggest that a state's location influences its enactment of fee shifting statutes.

Since region may have an effect upon the overall number of fee shifting statutes enacted, it is also appropriate to inquire whether certain types of fee shifting statutes seem to be more prevalent in some regions than others. The correlation of region with attorney fee shifting statutes' subject matters did reveal that certain

57. The four easternmost regions are: the Mid-Atlantic, New England, Southeastern, and Southern.

58. These four states are Colorado, New Mexico, Utah, and Wyoming.

59. These eleven states are Alabama, Arkansas, Delaware, District of Columbia, Georgia, Kentucky, Maryland, North Carolina, Tennessee, Virginia, and West Virginia. 
types of fee shifting statutes were relatively more prevalent in some regions than other regions. A brief listing of the most significant results follows.

The Mid-Atlantic region accounts for a high number of attorney fee shifting statutes in the corporate (9) law area. While corporation statutes account for only $2.8 \%$ of the national total of statutes in this survey, corporation statutes account for $5.2 \%$ of the Mid-Atlantic's fee shifting statutes. ${ }^{60}$ In contrast, the Midwest region accounts for a relatively high number of utility (20) and civil rights (13) fee shifting statutes. For example, utility statutes account for $6.1 \%$ of the Midwest region's attorney fee shifting statutes, but only $3.2 \%$ of the national total. Surprisingly, the Mountain region has a high number of corporate (11) fee shifting statutes, while having only one agricultural fee shifting law. The New England states have enacted a very high number of consumer (21) and tort (8) fee shifting statutes.

While the percentage of general litigation fee shifting statutes found in the Pacific region is unsurprisingly low $(10 \%),{ }^{61}$ the region has enacted a relatively high number of agriculture (10), assessment (19), civil rights (43), general trade regulation (29), property (43), tort (24), and water (16) attorney fee shifting statutes. Of particular interest is the very high number of tort and water attorney fee shifting statutes. ${ }^{62}$ Nevertheless, the high number of these types of statutes may be explained by looking at regional interests. For example, the expansion of tort liability in California might have affected enactment of attorney fee shifting laws in this area. In addition, the high number of water rights attorney fee shifting statutes reflect greater concern about water supplies in an arid and increasingly populated west coast. Finally, the southern region accounts for a high number of environment (12), agriculture (14), and taxation (8) fee shifting statutes.

Of course, without in-depth statistical analysis and a greater inquiry into these regions, the significance of these deviations from national percentages is uncertain. Nevertheless, prevalence of a certain type of attorney fee shifting statute within a region may indicate a problem of regional importance.

\section{Historical Analysis of State Attorney Fee Shifting Laws}

This section looks at the enactment of attorney fee shifting statutes over time. Before embarking on the analysis, however, it is again important to remember that the survey looked at those statutes currently in force. Thus, the low number of older statutes may not fully reflect the actual number of statutes enacted in earlier decades. Nevertheless, the authors believe that the included statutes present a sufficient basis for some general conclusions and explanations.

As noted by table 12 and graph 1 , only $20.5 \%$ of all attorney fee statutes currently in force were enacted before 1950. Beginning in the 1950's, however,

60. Delaware with its liberal corporation laws has no corporate fee shifting statutes.

61. Without including Alaska, the percentage of general litigation fee shifting statutes in the Pacific region drops to $7.5 \%$.

62. While tort statutes account for $5.9 \%$ of the Pacific region's attorney fee shifting statutes, such statutes account for only $2.8 \%$ of the national total. Similarly, water statutes represent $4.0 \%$ of all the Pacific region's attorney fee shifting statutes, but only $1.5 \%$ of the national total. 
attorney fee shifting statutes have been enacted with increasing frequency. Indeed, $54 \%$ of all existing state fee shifting statutes have been enacted since 1970 ; however, as shown by table 12, the growth of attorney fee shifting statutes since 1970 has been fairly even, suggesting that the growth in this type of statutes has leveled off. This recent pattern suggests that attorney fee shifting statutes will continue to be enacted at a high but fairly stable level.

The recent increase in fee shifting statutes is probably due to a number of factors. Indeed, two of the reasons for this increase may be the recent rise in legal fees, and a greater awareness by legislatures as to the many purposes that can be accomplished by such statutes.

Besides looking at the historical evolution of attorney fee shifting statutes as a whole, however, the authors also compared date of enactment with geographical region, subject matter, and purpose.

TABLE 12

\section{ENACTMENT Distribution}

\begin{tabular}{lcc} 
Time Period & Total & Percentage \\
\cline { 2 - 3 }$\leq 1900$ & 96 & 4.86 \\
$1901-1910$ & 42 & 2.13 \\
$1911-1920$ & 45 & 2.28 \\
$1921-1930$ & 43 & 2.18 \\
$1931-1940$ & 88 & 4.46 \\
$1941-1950$ & 91 & 4.61 \\
$1951-1960$ & 157 & 7.95 \\
$1961-1970$ & 340 & 17.22 \\
$1971-1980$ & 910 & 46.10 \\
$1981-1982$ & 162 & 8.21 \\
Total & 1974 & 100.00
\end{tabular}

\section{0-1982 DISTRIBUTION}

\begin{tabular}{ccc} 
Time Period & Total & Percentage \\
\hline $1971-1972$ & 144 & 7.3 \\
$1973-1974$ & 202 & 10.2 \\
$1975-1976$ & 181 & 9.2 \\
$1977-1978$ & 194 & 9.8 \\
$1979-1980$ & 189 & 9.6 \\
$1981-1982$ & 162 & 8.2 \\
Total & 1072 & 54.3
\end{tabular}

1. Geographical Region. An examination of the enactment dates of state attorney fee shifting laws within each geographical region revealed that all the regions have essentially followed the national growth pattern. The regions with the largest number of attorney fee shifting statutes (Pacific, South Central, and Midwest 
GRAPH 1

EnACTMENT TRENDS

1000

900

800

(910)

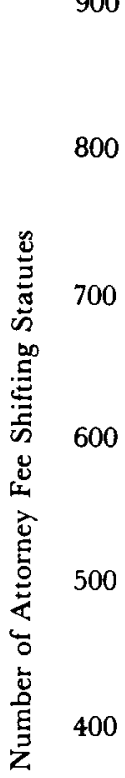

300

200

100

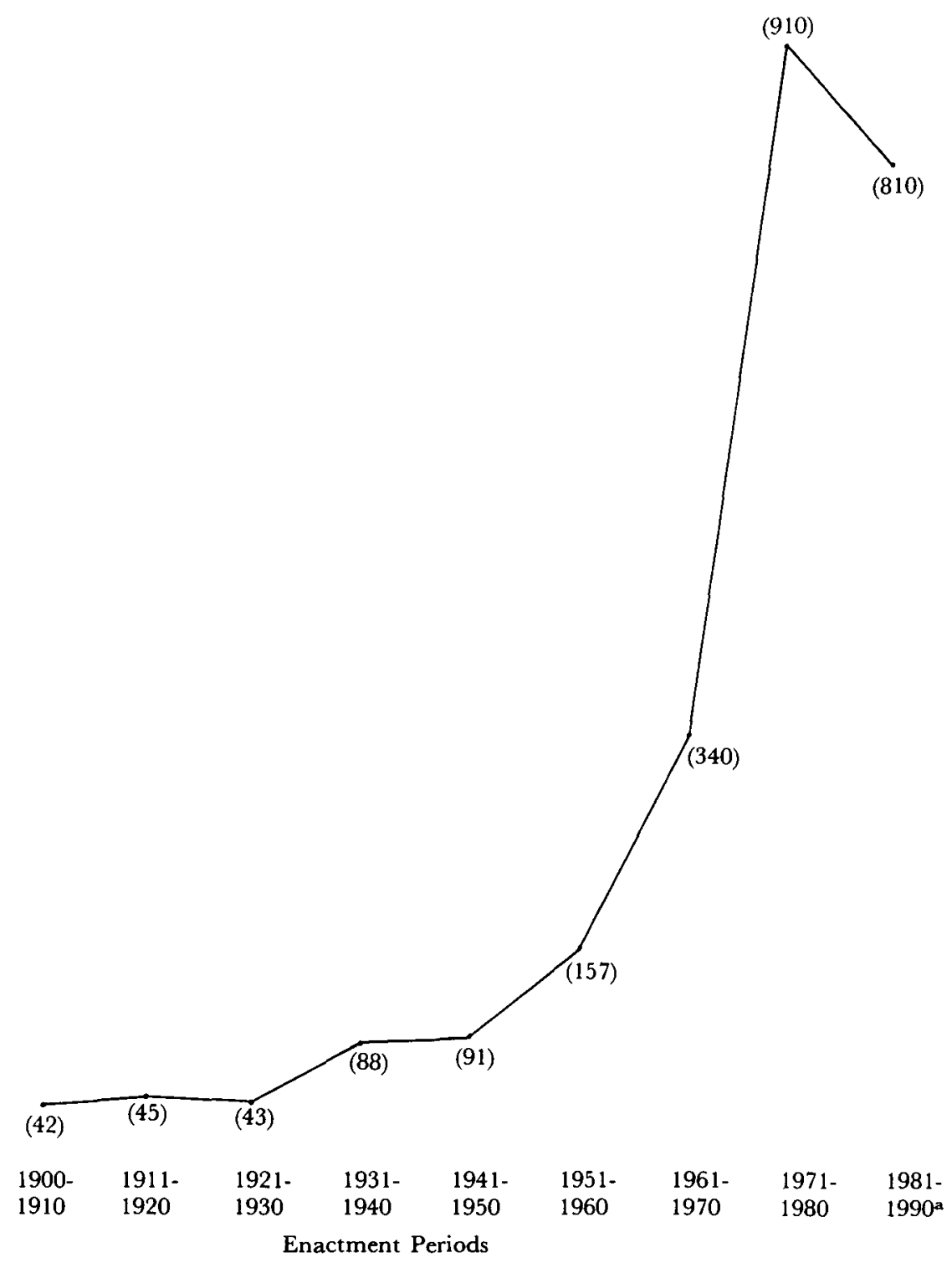

a The 1981-1990 number represents a projection using the 1981-1982 figures as a base.

regions) have experienced slower percentage growth in fee shifting statutes over the last 20 years than those regions with fewer statutes. This result, however, 
merely indicates that before 1960, these regions already had enacted a substantial number of attorney fee shifting statutes.

2. Subject Matter. While $71.5 \%$ of the nation's fee shifting statutes have been enacted since 1960, this growth has not been uniform across subject matters. Accordingly, this subsection looks at these subject matters that differ significantly from the national growth rate and explores some possible explanations.

For example, $86 \%$ of existing general trade regulation statutes have been enacted since 1960. Indeed, 15 general trade regulation fee shifting statutes have been enacted since 1980, possibly signalling strong growth of fee shifting statutes in this area. Similarly, $93.2 \%$ of all consumer attorney fee shifting statutes have been enacted since 1960. Moreover, environmental attorney fee shifting statutes have also experienced rapid growth recently, with $81.6 \%$ being enacted since 1960 . Rental housing attorney fee shifting statutes have also experienced rapid growth; only one shifting statutes was enacted before 1960. Similarly, family (80.2\%), crime $(96.8 \%)$, tort $(91.1 \%)$, banking $(80 \%)$, civil rights $(87.2 \%)$, and education $(80 \%)$ attorney fee shifting statutes have all experienced rapid growth since 1970.

In contrast, a few subject matters have not experienced such rapid growth. Only $22.9 \%$ of general assessment statutes have been enacted since 1960 . Indeed, enactment of these statutes has appeared fairly uniform over the years. Taxation (28.6\%) and utility (34.4\%) statutes have also experienced relatively slow growth since 1960. The slow growth of the utility attorney fee shifting statutes may be somewhat deceiving since a large number of these statutes were enacted before $1910(26.6 \%)$, probably in response to the growth of the railroad industry. Agriculture $(61.9 \%)$, corporation $(62.5 \%)$, debtor/creditor $(52.3 \%)$, insurance $(52.8 \%)$, water $(36.7 \%)$, and worker's compensation (48.6\%) attorney fee shifting statutes have also experienced relatively slow growth over the last two decades. ${ }^{63}$

3. Purpose. Plotting purpose across times, as noted by table 13 , demonstrated that legislatures are increasingly emphasizing equalization, indemnity, and public interest purposes in enacting statutes. For example, $80.5 \%$ of all public interest attorney fee shifting statutes have been enacted since 1960. Moreover, the percentage of public interest statutes as compared to the other statutes is growing. For example, $8.8 \%$ of all the statutes enacted between 1941 and 1950 had public interest purposes. During 1970 to 1980 , the percentage of attorney fee shifting statutes with public interest purposes had risen to $19.5 \%$. Indemnity and equalization statutes have also experienced rapid growth since 1960.

In contrast, full compensation attorney fee shifting statutes, although still being enacted in large numbers, have experienced slower percentage growth; only $60 \%$ of full compensation statutes have been enacted since 1960. Also, the proportion of full compensation statutes to statutes with other purposes has declined steadily

63. The remaining subject matter categories experienced growth similar to the national growth trend. The following list provides the percentage of statutes in each remaining category which were enacted after 1960: antitrust $(67.0 \%)$, general litigation $(77.2 \%)$, labor $(66.4 \%)$, public health $(68.6 \%)$, property $(66.2 \%)$, securities $(73.9 \%)$, and state violations $(75.6 \%)$. 
since the 1920 s-from $67.4 \%$ in $1921-1930$ to $31.5 \%$ in $1970-1980$. Thus, legislatures are not using attorney fee shifting statutes for a single purpose, but are increasingly emphasizing a variety of purposes.

TABLE 13

PurPosea OVER TIME

\begin{tabular}{|c|c|c|c|c|c|c|c|}
\hline & & $\begin{array}{c}\text { Full } \\
\text { Compensation }\end{array}$ & Punitive & $\begin{array}{c}\text { Litigation } \\
\text { Control } \\
\end{array}$ & $\begin{array}{l}\text { Public } \\
\text { Interest } \\
\end{array}$ & $\underline{\text { Indemnity }}$ & Equalization \\
\hline & $\leq 1900$ & 46 & 26 & 19 & 12 & 10 & 10 \\
\hline $1909-$ & -1910 & 27 & 14 & 2 & 7 & 3 & 3 \\
\hline 1911. & -1920 & 24 & 14 & 9 & 3 & 6 & 4 \\
\hline $1921-$ & -1930 & 29 & 10 & 5 & 1 & 4 & 6 \\
\hline $1931-$ & -1940 & 63 & 24 & 15 & 10 & 4 & 3 \\
\hline $1941-$ & -1950 & 44 & 31 & 25 & 8 & 4 & 7 \\
\hline 1951 . & - 1960 & 62 & 50 & 48 & 22 & 7 & 13 \\
\hline 1961. & - 1970 & 109 & 110 & 120 & 49 & 36 & 35 \\
\hline $1971-$ & -1980 & 287 & 310 & 284 & 178 & 107 & 101 \\
\hline 1981 . & - 1982 & 51 & 58 & 43 & 34 & 26 & 20 \\
\hline TOTA & $A L$ & 742 & 647 & 570 & 324 & 207 & 202 \\
\hline
\end{tabular}

a It is important to remember that each statute may have more than one purpose. See supra p. 327.

\section{IV}

\section{Effect of State Attorney Fee Shifting Statutes}

Although the survey focused on the descriptive and historical features of state attorney fee shifting statutes, the authors also sought to ascertain the effect of these statutes on actual litigation. Unfortunately, a detailed inquiry into the effect of these statutes was difficult since an examination of the judicial application of each statute would have proven prohibitively time consuming. Nevertheless, the authors were able to form some general impressions by using two limited search techniques.

The authors spot-checked a sampling of state cases to see if attorney fee shifting statutes were being used. ${ }^{64}$ This cursory sampling of cases revealed that state attorney fee shifting statutes are having some effect upon the American rule, espe-

64. This sampling of cases was accomplished by using simple search strategies on Lexis. For the five surveyed states-Alabama, Alaska, California, Kansas, and Oregon-the authors first identified, using Lexis, a limited number of 1982 reported cases that could easily be searched in order to find whether attorney fee shifting statutes were having any impact. For example, for Kansas, the authors identified 100 reported 1982 cases as their base sample. Having identified a group of cases to search, the authors then searched these cases for cases mentioning "attorney fees" or "attorney costs." Those cases mentioning "attorney fees" or "attorney costs" were then individually examined to determine whether the case's discussion of attorney fees was in connection with a state attorney fee shifting statute. These latter cases, therefore, are the ones that indicate whether state attorney fee shifting laws are having an impact upon the American rule. 
cially in those states with large numbers of attorney fee shifting statutes. In a sampling of 100 reported California appellate cases, the authors found that in 7 of these cases the award of attorney fees was governed by a statute and mentioned in the court opinion. An examination of Oregon reported cases also revealed a number of cases in which an attorney fee award was required by statute. In contrast a sampling of approximately 100 Kansas cases revealed only 4 cases in which an attorney fee shifting statute governed an award of attorney fees. Finally, a sampling of 100 cases from Alabama revealed only one case in which an attorney fee award was dictated by a statute. It is probable, however, that a survey of reported civil cases, which were exclusively appellate cases, would underestimate the influence of state fee shifting statutes because the fact that a particular case is governed by an attorney fee shifting statute may not be mentioned on appeal.

As a second method for ascertaining the effect of attorney fee shifting statutes upon the American rule, the authors briefly scanned the annotations following each statute. This review of annotations indicated that, while a number of statutes showed substantial use, the majority of fee shifting statutes showed little, if any, use. Again, one must be careful not to read too much into this finding since the lack of annotations under a statute may merely represent the newness of the statute or a lack of controversy concerning its interpretation. Nevertheless, the lack of use of large numbers of state attorney fee shifting statutes does suggest that lawyers may be ignorant of their existence.

Admittedly, this analysis into the impact of these state attorney fee shifting law is less than conclusive. Nevertheless, the limited examination into this subject suggests that, at present, these statutes are having some effect. In particular, the appearance of fee award discussion in a substantial number of reported civil appeals in two states (California and Oregon) among those in the nation having the largest number of fee shifting laws may be the tip of a fairly large iceberg. In Alaska, where fee shifting is the general practice and, thus, likely involved in a majority of civil cases, the authors found discussion of fee award issues in only about one-fifth (56 of 266) of reported civil appeals surveyed. For numerous reasons fee awards will not always be appealed or dealt with in appellate court opinions; so, if anything, the authors' necessarily brief and inconclusive surveys are likely to underestimate the incidence with which fee award statutes are invoked.

\section{VI}

\section{CONClusion}

The most surprising result of this survey was that there are so many attorney fee shifting statutes-at least 1,974. Indeed, this number probably underrepresents all state attorney fee shifting statutes, since the survey certainly did not uncover all state attorney fee shifting statutes and since states continue to enact fee shifting laws. ${ }^{65}$ Nevertheless, the survey results highlight the diversity of state fee shifting statutes. Not only are fee shifting statutes being enacted in many subject matters;

65. In California, for example, over fifteen new fee shifting statutes have been enacted since the survey was concluded. 
but-unlike the English rule which provides a uniform method of fee shiftingsuch statutes are being drafted in a variety of ways, demonstrating that legislatures are trying to accomplish a variety of purposes with these statutes.

This survey also is significant in that it demonstrates that fee shifting statutes have not been enacted with equal vigor in every state. Indeed, there are a number of states that have not taken any substantial action to deviate from the American rule. Finally, strong growth in attorney fee shifting statutes over the last two decades suggests that state attorney fee shifting statutes will continue to be enacted on a fairly large scale. Thus, the survey, on the whole, demonstrates a strong, but selective and partial, legislative effort to deviate from the American rule.

The actual impact that state attorney fee shifting statutes are having upon the American rule is unclear. Despite this uncertainty, however, the authors' brief review of reported cases did reveal that these statutes, although not having an overwhelming effect, are having some impact upon the traditional American rule, especially in those states that have large numbers of attorney fee shifting statutes. Indeed, the impact of these statutes on the American rule will likely increase as more are enacted and awareness of them increases. 